\title{
Architecture_MPS
}

\section{Rebranding the Neoliberal City: Urban Nature as Spectacle, Medium, and Agency}

Joern Langhorst ${ }^{1}$

How to cite: Langhorst, J. 'Rebranding the Neoliberal City: Urban Nature as Spectacle, Medium, and Agency.' Architecture_MPS, 2015, 6(1): 4, pp. 1-16. DOI: https://doi.org/10.14324/111.444.amps.2015v6i4.001.

Published: 01 February 2015

\section{Peer Review:}

This article has been peer reviewed through the journal's standard Editorial double blind peer review.

\section{Copyright:}

(C) 2015, The Author(s). This is an Open Access article distributed under the terms of the Creative Commons Attribution License (CC-BY) 3.0 https://creativecommons.org/licenses/by/3.0/, which permits re-use, distribution and reproduction in any medium, provided the original author and source are credited • DOI: https://doi.org/10.14324/111.444.amps.2015v6i4.001

\section{Open Access:}

Architecture_MPS is a peer-reviewed open access journal. 


\title{
Title: Rebranding the Neoliberal City: Urban Nature as Spectacle, Medium, and Agency
}

\section{Joern Langhorst}

\author{
Architecture_media_politics_society. vol.6, no.4.
}

February 2015

Affiliation: College of Architecture and Planning, University of Colorado, Denver

\begin{abstract}
:
Post-industrial sites are frequently seen as aesthetically sublime, considered as iconic reminders of an ongoing de-industrialization, and interpreted as symbols of the failure of the industrial age. Simultaneously they are also locations to re-imagine, reinvent and recover landscapes as agents for essential, sustainable, and environmentally-just urban transformations. The most visible discourses on post-industrial urban sites emphasize issues of environmental justice, pollution mitigation, adaptive reuse, and, in the context of urban redevelopment and renewal, benefits and performances based on ecological functions and processes. On the one hand, current concepts such as "landscape urbanism", "sustainable urbanism" and "ecological urbanism" (as conceptual and practical alternatives to the mainstream forces of urban development) suggest ecology as a redemptive agent. Conversely, established and new hegemonial agendas of global development and neoliberal capitalization focus on political and economic interests involved in the complex processes of urban renewal, gentrification, redevelopment.
\end{abstract}

These competing discourses construct post-industrial sites as highly contested terrains, and variously instrumentalize emergent ecologies and "urban nature". Post-industrial sites themselves can be decoded as physical manifestations (material) - and representations (medium) - of such discourses. In this context, the present paper analyzes the High Line in New York City, one of the most recent iconic design projects on a post-industrial urban site. It draws on WJT Mitchell who frames city and urban space as "both represented and presented space, both a signifier and a signified and uses the idea that spaces operates simultaneously as real place and a way of seeing. It will argue that the agency of physical and material change in urban spaces extends beyond its economic, functional and ecological performances into the aesthetic-representational practices of "seeing" and "being seen". 


\title{
Title: Rebranding the Neoliberal City: Urban Nature as Spectacle, Medium, and Agency
}

\author{
Authors: Joern Langhorst
}

Architecture_media_politics_society. vol.6, no.4.

February 2015

\begin{abstract}
"Change life! Change Society! These ideas lose completely their meaning without producing an appropriate space." Henri Lefebvre ${ }^{1}$

"(Social) space is a (social) product [...] the space thus produced also serves as a tool of thought and of action [...] in addition to being a means of production it is also a means of control, and hence of domination, of power." Henri Lefebvre ${ }^{2}$
\end{abstract}

Post-industrial sites are frequently seen as aesthetically sublime, considered as iconic reminders of an ongoing de-industrialization, and interpreted as symbols of the failure of the industrial age. Simultaneously they are also locations to re-imagine, reinvent and recover landscapes as agents for essential, sustainable, and environmentally-just urban transformations. Both understandings mythologize and value such places, employing a fundamentally dichotomic and normative ${ }^{3}$ construction of 'culture' and 'nature' that implicitly relies on the visibility and representational agency of such sites. The most visible discourses on post-industrial urban sites emphasize issues of environmental justice, pollution mitigation, adaptive reuse, and, in the context of urban redevelopment and renewal, benefits and performances based on ecological functions and processes. On the one hand, current concepts such as "landscape urbanism," "sustainable urbanism," and "ecological urbanism,", (as conceptual and practical alternatives to the mainstream forces of urban development), suggest ecology as a redemptive agent. Landscape Urbanism in particular emphasizes process over finished static form, positing landscape and place as both results of cultural production and agents for cultural change. They approach intentional environmental change by attempting to engage the inherent openendedness, dynamic qualities and interrelatedness of human and non-human processes and systems, ${ }^{5}$ and include various interests, processes and forces excluded in more traditional planning approaches. ${ }^{6}$

Conversely, established and new hegemonial agendas of global development and neoliberal capitalization (with their attendant less obvious and less public discourses) continue to focus on political and economic interests involved in the complex processes of urban renewal, gentrification, 
redevelopment and rebranding, producing economically, socially and environmentally uneven and unjust conditions. ${ }^{7}$ These competing discourses construct post-industrial sites as highly contested terrains, and variously instrumentalize emergent ecologies and "urban nature" Post-industrial sites themselves could then be decoded as physical manifestations (material)- and representations (medium) -of such discourses, ultimately forcing a reconsideration of ecology and "urban nature" from an objective construct of descriptive science (focusing on biophysical aspects) to a contextually complex hybrid, involving cultural, political, economic and biophysical aspects.

In this context, this paper analyzes the High Line in New York City, one of the most recent iconic design projects on a post-industrial urban site. It develops a framework that complements the traditional focus on material-physical-capital-ecological performances in the production and reproduction of contemporary concepts of "sustainable" and "green" cities, particularly referencing the current discourses on "landscape urbanism," "emergent ecologies." and "urban nature." It draws on WJT Mitchell ${ }^{8}$ who frames city and urban space as "both represented and presented space, both a signifier and a signified, both a frame and what a frame contains, both a real place and its simulacrum (...)." Using the idea that spaces operate simultaneously as real place and a way of seeing, as a sensibility and a lived relation, it will be suggested that urban space then is both medium and mediated. Furthermore, it will be argued that the agency of physical and material change in urban spaces extends beyond its economic, functional and ecological performances into the aestheticrepresentational practices of "seeing" and "being seen."

\section{Urban Nature(s) and Environmental Justice:}

Underlying the arguments put forward here is the proposition that the "right to the city," historically defined as an issue of social and (to a degree) environmental justice, ${ }^{10}$ also implicitly comprises a right to urban nature. The term 'urban nature' is in itself ambiguous, ${ }^{11}$ but is frequently used to describe spontaneous vegetation and other expressions of non-human processes within densely built and controlled urban developments. Emergent ecologies can be considered the most authentic ${ }^{12}$ elements of urban nature, as they are the physical expressions of processes that are not controlled by human maintenance regimes and are most often manifested in early stage successional vegetation. They may be interpreted as nature's "spatial tactics"13 and acts of resistance, occupying space (both marginal and marginalized) that are uncontrolled or less controlled by dominant processes of development and capital accumulation. Consequently, they should be more appropriately understood and labeled as transgressive ecologies. $^{14}$

Access to - and experiences of - urban nature or of 'nature' in general is a primary issue when assessing their agency. As urban nature is produced (or is allowed to produce itself) on post-industrial sites, questions of the types and distribution of nature, and how they impact the life of people in their proximity become a concern. ${ }^{15}$ This is underlined by the fact that most post-industrial sites occur in neighborhoods that are characterized by a lack of parks and other open space, below-average environmental quality, and are frequently inhabited by communities that are affected by the very processes of industrialization and deindustrialization that created such sites in the first place. In this context, the main agency of post-industrial sites, whether in their redeveloped / redesigned or 
abandoned state, might not lie primarily in their actual and potential ecological functions and performances, ${ }^{16}$ but more in their aesthetic and representational function.

\section{Representing Landscape and Landscapes of Representation:}

The representational agency ${ }^{17}$ of landscape and space itself, its ability to represent ideas and ideologies, is particularly potent if it is intentionally designed. Its representational capacity relies heavily on aesthetic qualities, often foregrounding passive visual reception (appearance) over all other forms of sensory experience. The way in which underlying ideas inform and correspond to spatial and material form, and determine regimes of maintenance and control, is frequently deeply encoded, and not obvious. The decoding of designed and professionally curated spaces and landscapes depends on a particular situated ${ }^{18}$ knowledge of aesthetic and ideological traditions of landscape architectural or architectural design - and on the long-standing complicity of spatial design and planning professions with hegemonial agendas. However, designed landscapes are (due to their experiential qualities) capable of representing ideas, ideologies and underlying values independent of an audience's ability to decode them - an ability that grants them insidious power.

In the context of post-industrial landscapes and urban redevelopment their ability to perform and represent ideas about the relationship between human and non-human processes (between "nature" and "culture") by providing and presenting various patterns and systems of order, is central. The (primarily visual) order of the urban fabric and its varied elements and components is not just important in decoding the layout and makeup of the physical identity and order of "city" as a means to orient oneself in response to the visual identities of environment, as explored in Kevin Lynch's "Image of the City." 19 The visual agency of the urban fabric extends into attendant meanings and associations of order and pattern, representing ideas and forms of social, political and cultural order and hierarchy putting people not just in a physical location but in "their place" within a social/capital order.

This discourse is located in the larger contexts of "sustainable" urban (re-)development, the "ecological city" and the very notion of "urbanity" itself. Urban (public) space is a central issue in conversations on globalization; the post-political erosion of the urban public sphere associated with austerity and resilient neoliberal governmentality ${ }^{20}$ and in debates on the transformative potential of the urban field. ${ }^{21}$ Embedded in this is the belief that the representational agency of urban space is central to understanding and facilitating processes of urban change and an important addition to the traditional focus on economic or physical-functional performances - in particular in the context of social and environmental justice and the "right to the city." Deconstructing urban space and its existing and artificial morphologies and ecologies as physical manifestations (material) and representations (medium) of these discourses helps to decode its character as both result of and active agent in the capital-cultural production of urbanity itself. This widened perspective forms a basis for critical urban studies understood as a counter-hegemonic history of the past and present.

\section{The High Line: Ruining the Ruin, or Post-Industrial Sites as Picturesque Artifacts:}

The High Line on the West side of Manhattan started as an elevated freight rail track in the 1930s and 
was eventually decommissioned in 1980. Left unmaintained, spontaneous successional ecologies developed. Iovine describes the High Line during this time as "a figment of people's romantic imagination - a wild meadow threaded with rusty nails high above the street that was visited primarily by adventuresome truants and graffiti artists." ${ }^{22}$ In the context of the 1990s urban renewal in surrounding neighborhoods (Meatpacking District and Chelsea), the perceptions of the High Line changed. The not-for profit Friends of the Highline increasingly gained traction in their quest for its preservation and development as an elevated park, an urban promenade, aligning with powerful interests and agendas pushing thus further urban renewal and gentrification in the surrounding neighborhoods. ${ }^{23}$ After a number of complex real estate deals, the swapping of development and air rights, and the securing of financing through public-private partnerships, New York firms Field Operations (landscape architecture) and Diller Scofidio+Renfro (architecture) won an open design competition. $^{24}$

Rather than embracing the existing qualities and agents of the location, the High Line's design operates in the traditions of the 'picturesque' - a concept rooted in enlightenment romanticism that was fundamental in the development of landscape architecture as a field, discipline and practice in the $18^{\text {th }}$ and $19^{\text {th }}$ Century, translating "techniques, formal strategies, and subject matter of Romantic paintings into the design of landscapes." ${ }^{25}$ It is noteworthy that Field Operation's principal James Corner's argues for the primacy of process and performance over form, and dismissed the picturesque as an outdated, reductive and inappropriate approach to the design and understanding of landscape. ${ }^{26}$ The design removed the existing 'wild' emergent and transgressive ecologies and the gritty appearance of an industrial ruin, replacing them with carefully designed and choreographed artificial ecologies, and with slick, sophisticated design elements with refined materials and finishes. It disappointed expectations of retaining at least some of the High Line's existing emergent ecologies, upsetting photographer Joseph Sternfeld, whose photographs of the pre-design High Line and its iconic and sublime qualities created by the interplay between the decaying industrial ruin and emergent ecologies had been instrumental in garnering public support. ${ }^{27}$ 


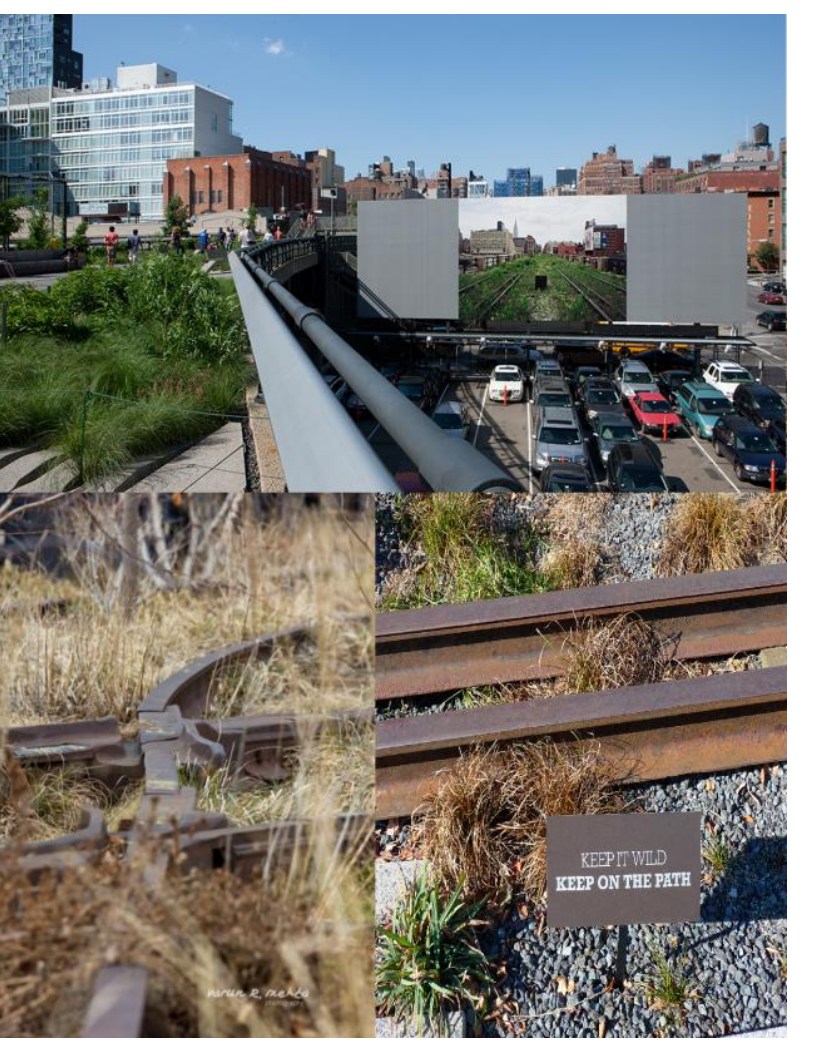

Figure 1:

Constructing the picturesque: before - after (photos: author). Note Robert Sternfeld's photograph on the billboard, as seen from the redesigned High Line (photographs by the author).

\section{Performing Aesthetics, or the Building of an Image:}

The High Line provides a highly controlled, choreographed and pretexted experience. It foregrounds visual experience and is thus akin to a promenade with a sequence of tableaus designed to be seen, but not otherwise interacted with. The planting design as well as the placement of benches, viewing platforms etc., enforces a particular experience and ocular regime, with little possibility for deviation. Behaviour is tightly controlled and regularly enforced by other visitors and the ubiquitous presence of maintenance staff and park police. The exclusion of visible manifestations of non-human processes ${ }^{28}$ makes impossible meaningful and formative experiences of a more authentic type of urban nature that could be considered challenging or resistant to the hegemonial agendas of urban renewal. By contrast, it constructs and maintains the line as an exclusive aesthetic object, by controlling any type of experience and interaction.

Aesthetic experience ${ }^{29}$ is reduced to the act of looking and any experience that is not merely visual and limited to passive reception is explicitly discouraged and policed accordingly. Thus it reminds us of DeCerteau ${ }^{30}$ who contrasted the participatory and immersive practices of the urban dweller from those of the mere voyeur in the production of urban space, pitting autochthonous, direct and active experience against the detached and passive consumption of urban space as imagery. 
Past and contemporary concepts and experiences of urban space then are not just generated through the production of images, but in fact through the production of urban space itself as an image to be consumed and interacted with. This aestheticizes and reduces complex lived experience, producing a narrow range of acceptable meanings and behaviors that replaces the aesthetics of performance (aesthetic experience of processes and their resultant physical-material expressions) with a performance of aesthetics (the experience of a constructed, "finished" spatial-physical condition - a "product" and its attendant aesthetics).

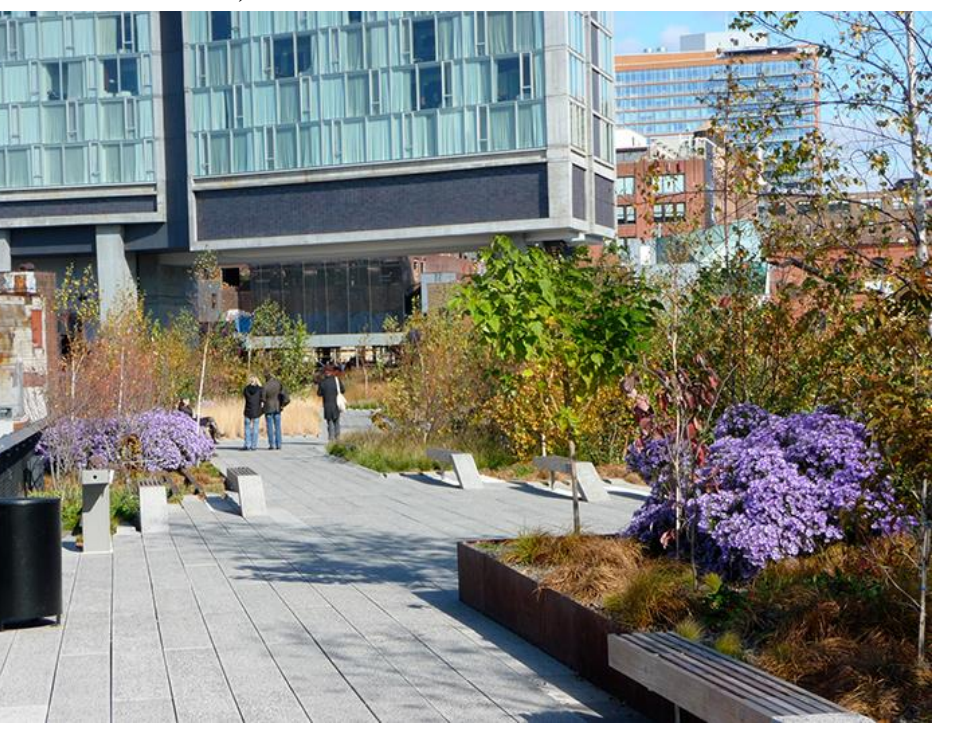

Figure 2:

High Line Experience. (photograph by the author).

Most picturesque works of landscape architecture produce explicit and implicit narratives. ${ }^{31}$ The High Line - operating in the tradition of an $18^{\text {th }}$ or $19^{\text {th }}$ century promenade - moves the visitor from woodlands to grasslands, to trees and shrubs, to grasslands, back to an area of denser woodland vegetation, and grasslands at phase 2 's northern terminus on $30^{\text {th }}$ street, generating an almost cinematic sequence. The focus on the spectacle in the foreground and the experience of different ecotypes in succession suggests a narrative of a pristine pastoral nature that excludes the surrounding urban conditions and replaces the possibility of a critical engagement with the processes and the parameters of its social, cultural and capital production in an urban context with notions of escapism. ${ }^{32}$

\section{Visual Practices and Aesthetic Justice: Naturalizing Power, Mediating Contestation and Re- Branding Urban Renewal:}

Traditional picturesque aesthetics and ideology emphasize the visual and are ultimately exercises in the production of images with distinct and hidden agendas. The High Line's aesthetic performance operates within this framework. The rebranding of the Lower West Side relies on the production of images (of city, urbanity, nature, culture etc.), and the High Line operates simultaneously as visual aesthetic object and as a "viewing platform" - a device that facilitates privileged views of the city. 

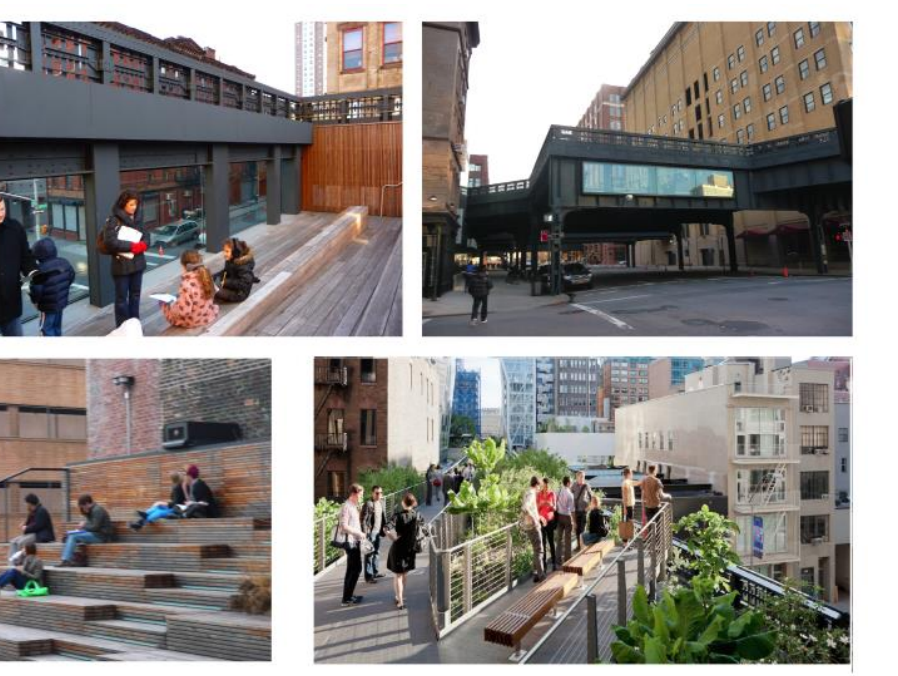

Figure 3:

"Staging" performances on and of the High Line. (photographs by the author).

It is rendered a stage on which the (acceptable) expressions of contemporary constructions of urbanity are acted out, deliberately including and excluding certain participants and behaviors. A critical perspective on this "performance of aesthetics," then should interrogate what exactly is being performed, who writes the script, and who enacts it. The High Line illustrates Habermas ${ }^{, 33}$ and Fraser's $^{34}$ disquisitions into the public sphere and different publics (hegemonial, counter- and subaltern), and supports their contention that particular spatial-material constructions of "public space" tend to enforce particular public social identities, producing and reproducing particular attitudes and behaviors.

Traditional picturesque ideology has deployed its aesthetics to successfully hide the actual authorship of space and succeeded in 'naturalizing' hegemonial power. The High Line operates along similar lines - by its exclusion of transgressive human and non-human processes and their physical manifestations, it erases the possibility of encountering a more authentic and inclusive version and vision of urban nature. It replaces it with a reductive, domesticated artifact - an artifact that cements and expands existing power differentials, excluding ideas about the relationship between human and non-human processes that might challenge the hegemony of global capital flows in imagining alternative versions of urbanity and urban development. 


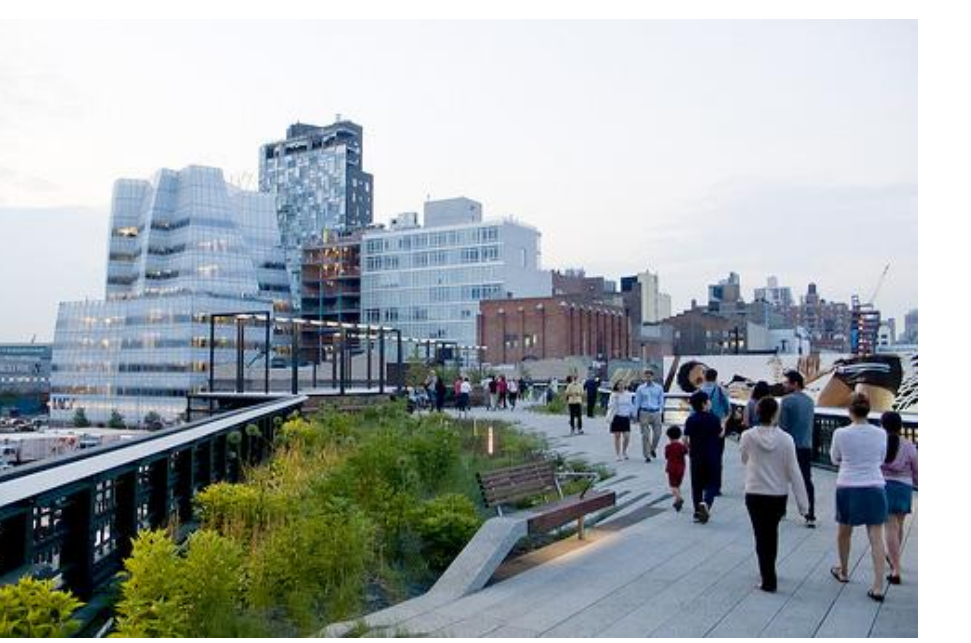

Figure 4:

Visual practices in action: seeing and being seen. Note new real estate development in background.

(Photograph by the author).

Images themselves tend to be static, producing an appearance that is at odds with the remembered experience of dynamic change. In line with the picturesque tradition, images privilege particular spatial conditions (the perspectival construction of imagery privileges one particular point of view, and one particular direction of the gaze), but they also pick one particular moment in time, thus limiting the ability to imagine any kind of change. The High Line, as a translation of such imagery, clearly suggests a static imagination of urban nature - a domesticated version that is predictable and benevolent, ${ }^{35}$ subtly invoking ideas about non-human systems as homeostatic, balanced, and ultimately 'sustainable ${ }^{36}$ - this sustainability being achieved without challenging capitalist-hegemonial systems and their obvious production of environmental inequality. ${ }^{37}$

The High Line then constructs urban nature as a picturesque garden, excluding the emergent and transgressive ecologies, and the non-human processes they are actually produced by and signify. Its actual performance is relegated to aesthetic appearance. As such, the High Line's primary agency lies in the performance of (ecological) aesthetics, rather than an aesthetics of (ecological) performance. ${ }^{38}$ This rendering it as a "spectacle" 39 or as "hyperreality" 40 in which the signifier (High Line's domesticated version of urban nature) replaces the signified (nature and non-human processes, expressed as emergent ecologies), revealing aesthetic and representational processes through which urban space is involved in its own production and reproduction.

The "new appropriation" ${ }^{41}$ of the picturesque, as ideological and representational tool in the capitalisthegemonial control of emergent constructs of ecology, urban nature, and urbanity, serves the stabilization and control of uneven developmental patterns and emphasizes the shifting role of landscape in this context: Cosgrove argues that "...landscape constitutes a discourse, through which identifiable social groups historically have framed themselves, and their relations, with both the land and with other human groups, and that this discourse is closely related epistemically and technically to ways of seeing...."42 The discourse on replacing ('domesticating') the transgressive elements of urban nature on the High Line is played out through the production of imagery and actual (aesthetic) experience of landscape, reducing it to its representational content and semiotic function as a signifier. $^{43}$ 


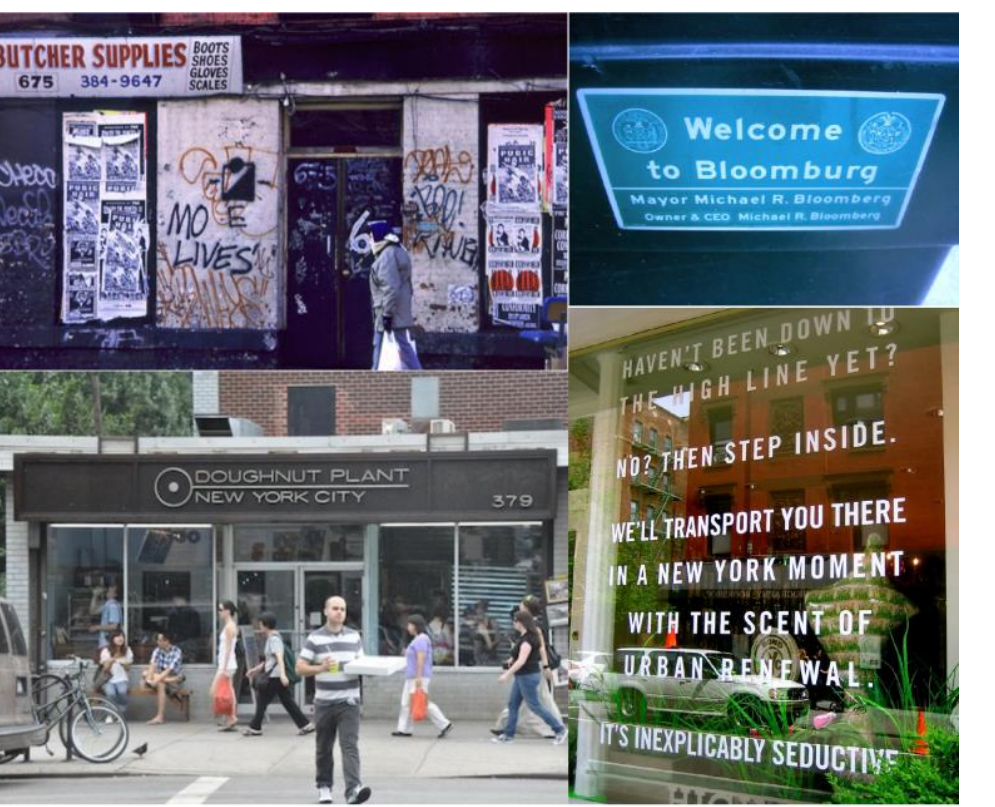

Figure 5:

The replacement of the socially transgressive. (Photographs by the author).

\section{Conclusion:}

The replacement of the ecologically transgressive corresponds to the exclusion and displacement of the socially transgressive (paralleled by the "clean-up" of the Meatpacking District with its pasts of marginal industrial production and subsequent image of sexual deviancy ${ }^{44}$ ). The physical expression of previous "layers" of urban culture are de facto erased, and the structure of the High Line, while remaining, is de facto relegated to the function of a "picture frame." In this context, the High Line operates as a powerful sign, an icon and symbol, that represents, advertises and "mediates" a neoliberal version of urban renewal. Urban renewal and gentrification processes were already well on their way, and had displaced large numbers of the poorer residents before the High Line, but it will without doubt be instrumental in accelerating these processes.

The High Line compellingly illustrates the essential and often underestimated role of aesthetic-visual practices and regimes inherent in - and materialized by - designed urban spaces. These territorialize and deterritorialize loci and processes of memory, meaning, place and community identity. In the context of urban renewal, abject gentrification and wholesale displacement of communities the role of urban space itself as medium cannot be underestimated. Spectacular projects, such as the High Line, play an increasing role the "branding" of cities. The use of iconic public buildings in urban renewal projects in disenfranchised, "transitional" neighborhoods has a long tradition, often referenced as the "Bilbao Effect." interacted with in different ways, and its (at least perceivably) more open access is much more insidious. 
The representational agency of the High Line is much more important to the re-branding of the Lower West Side than its ecological or physical-spatial performance. Much like iconic buildings, it is an inhabitable "cool" image. This approach, however, does become exceedingly problematic if the design of public open space is subjugated to the marketing and branding needs of what Mike Slater calls "the neo-liberal growth machine" ${ }^{* 6}$ and starts to disenfranchise or outright exclude demographics that do not, or cannot, participate in the processes of capital production and accumulation.

Any analysis of "urban space," "urbanity," and "city," then, needs to involve a thorough look at its representational agency and ideological content. Aesthetic justice, ${ }^{47}$ and the ability to actively participate in the experience, making, production and reproduction of different urban spaces that represent and reproduce different ideologies, concepts and attitudes becomes critical. It is also a necessary and, so far, neglected part of the discourses on the right to the city. ${ }^{48}$

\footnotetext{
${ }^{1}$ Henri Lefebvre, The Production of Space (Oxford: Basil Blackwell, 1991), 51.

${ }^{2}$ Ibidem, 26.

${ }^{3}$ For an overview of the fallacies and implications of this approach, see e.g. Casey 2009, Oelschlager 1991, Turner 1994, Cronon 1996, Corner 1997. To avoid the normative connotations of the traditional terms "nature" and "culture," the terms "non-human processes" and "human processes" are used when necessary.
}

${ }^{4}$ For an overview of the history and application of these concepts, see Corner 1999, Waldheim 2006, Mostafavi 2010.

${ }^{5}$ Swyngedouw (2010) introduced the term "socio-ecological assemblage" to conceptualize urban conditions and development processes.

${ }^{6}$ Landscape urbanism, in particular, has been criticized for fetishizing process and possibility over tangible outcomes, and being much more descriptive of existing conditions than generating ideas about future ones (Talen 2010).

${ }^{7}$ See David Harvey, Social Justice and the City (London: Edward Arnold, 1973); David Harvey, Rebel Cities: From the Right to the City to the Urban Revolution (London: Verso, 2012); Neil Smith, Uneven Development: Nature, Capital and the Production of Space (Oxford: Blackwell, 1984); Don Mitchell, Right to the City: Social Justice and the Fight for Public Space (New York: Guilford, 2003); Joern Langhorst, "Re-Presenting Transgressive Ecologies: Post-Industrial Sites as Contested Terrains," Local Environment: The International Journal of Justice and Sustainability, Special Issue on "Postindustrial Urban Ecologies (2014), DOI: 10.1080/13549839.2014.928813 and "The Resilience of Neoliberal Urbanism," Tom Slater, accessed 3 February 2014, http://www.opendemocracy.net/opensecurity/tom-slater/resilience-of-neoliberal-urbanism.

${ }^{8}$ WJT Mitchell, Landscape and Power (Chicago: University of Chicago Press, 1994), 1.

${ }^{9}$ As defined by David Harvey, Social Justice and the City (London: Edward Arnold, 1973); David Harvey, Rebel Cities: from the Right to the City to the Urban Revolution (London: Verso, 2012); Henri Lefebvre, "Right to the City," in Lefebvre, Writings on Cities, ed. E. Kofman and E. Lebas (Oxford: Basil Blackwell, 1996), 63-177 and Don Mitchell, Right to the City: Social Justice and the Fight for Public Space (New York: Guilford, 2003).

${ }^{10}$ Environmental justice in contemporary discourses emphasizes questions of environmental quality (such as air and water quality). I argue that the quality of the spaces inhabited by humans, both build and "natural" are an equally important component of environment, as they facilitate, mitigate, enable or discourage possibilities of interaction and inhabitation. This extended understanding of environmental justice aligns with Lefebvre's, Harvey's and Mitchell's concept of the "right to the city" as a right to participate in the physical, conceptual and ideal spaces that make up a city.

${ }^{11}$ As urban nature is continuously produced and reproduced by human and non-human processes and agents in varying spatial, material and temporal contexts, it would be more appropriate to use the plural 'urban natures'.

12 "Authentic" is obviously a highly contested concept in itself. The Oxford English Dictionary defines authentic as "real, actual, genuine, original, first-hand, really proceeding from its stated source" (OED, emphasis by author). In this sense, emergent and transgressive ecologies are indeed an unmitigated and un-manipulated result of non-human processes responding to the particular conditions of a site at a particular point in time. They are not "edited" by any human intervention.

${ }^{13}$ This applies DeCerteau's (1984) concept of spatial tactics, as they are employed by marginalized cultures against the spatial strategies of hegemonial elites in control of the mechanisms of spatial production. 
14 The concept of "transgressive ecologies" proposed here is developed as an analog to the framework of culturally transgressive behaviors laid out in Soja's "Thirdspace" (1996).

15 Jennifer Foster, "Off Track, in Nature: Constructing Ecology on Old Rail Lines in Paris and New York," Nature and Culture 5, no. 3 (2010): 318. See also Randolph Hester, Design for ecological democracy (Boston: MIT Press, 2006).

${ }^{16}$ Recent literature denotes an interest in the functional and performative aspects of ecosystems and landscapes, as denoted by discussions on "landscape as infrastructure" (Raxworthy \& Blood 2005, Poole 2005a and 2005b), "landscape performances" and "ecosystem services" (Hubacek and Kronenberg 2013).

17 James Corner, "Recovering Landscape as Cultural Practice," in Recovering Landscape: Essays in Contemporary Landscape Architecture, ed. James Corner (New York: Princeton Architectural Press, 1999), 2-26 and Denis Cosgrove, Social Formation and Symbolic Landscape (Madison: University of Wisconsin Press, 1998).

${ }^{18}$ Mitchell contends that "landscape itself is a physical and multisensory medium (earth, stone, vegetation, water, sky, sound and silence, light and darkness etc.) in which cultural meanings and values are encoded, whether they are put there by physical transformation of a place in landscape gardening or architecture, or in a place formed, as we say, by nature." Knowledge of the particular concepts and traditions within landscape architecture and related disciplines and professions can be considered privileged, as it is usually limited to members of these and related fields. "Contingent upon the thematic dimension of Picturesque works is the notion that their interpretation depends upon an educated reader" (WJT Mitchell, Landscape and Power (Chicago: University of Chicago Press, 1994), 14).

${ }^{19}$ Kevin Lynch, Image of the City (Cambridge: The M.I.T. Press, 1960).

${ }^{20}$ Japhy Wilson and Erik Swyngedouw, editors, The Post-Political and Its Discontents. Spaces of Depoliticisation, Spectres of Radical Politics (Edinburgh: Edinburgh University Press, 2014).

${ }^{21}$ Mark Purcell, The Down-Deep Delight of Democracy (Malden: Wiley-Blackwell, 2013) and Erik Swyngedouw, "Insurgent Urbanity and the Political City," in Ethics of the Urban: The City and the Spaces of the Political, ed. Moshsen Mostafavi (Zurich: Lars Müller Publishers, forthcoming).

${ }^{22}$ Julie Iovine, "All Aboard the High Line," The Wall Street Journal, 23 June 2009.

${ }^{23}$ For an excellent overview over the process of securing and building the High Line, see Cataldi et al. 2011.

${ }^{24}$ Both firms have a reputation as being on the cutting edge of design in urban conditions; both firms can be considered academic practices, as their principals hold faculty appointments at prestigious design schools known for the critical and innovative positions.

${ }^{25}$ Susan Herrington, "Framed Again: the Picturesque Aesthetics of Contemporary Landscapes," Landscape Journal 25, no. 1 (2006): 23. The resultant "pastoral" landscapes with their signature style (curving paths winding through undulating hills of grass punctuated by groupings of deciduous trees) continued to influence the formal conventions of public parks and private estates until the $20^{\text {th }}$ century - see e.g. Central Park in New York City.

${ }^{26}$ James Corner is the principal of Field Operations, one of the few contemporary writers on landscape architectural theory and one of the progenitors of the field of landscape urbanism (Corner, 1991, 1992, 1997, 1999).

${ }^{27}$ See Michael Cataldi et al, "Residues of a Dream World: The High Line, 2011," Theory, Culture, Society 28, no. 7-8 (2011): 358-389. Joel Sternfeld's photographs of the High Line, presenting it as an industrial ruin and its emergent ecologies as a form of urban wilderness and invoking ideas and visual experiences of the sublime (see Fig. 5), were hugely successful in branding the Highline and garnering public support. His photographs recall the role of paintings, etchings and photography in the rendering of 'wilderness' as a critical part of the early national park movement in the United States. His images (much reminiscent of $18^{\text {th }}$ and $19^{\text {th }}$ century landscape paintings) operate within and employ traditions of the picturesque, framing and rendering visible a post-industrial urban sublime and aestheticizing a form of urban nature where non-human processes insert and assert themselves into the margins and neglected interstices of the city. Interestingly, as much as Sternfeld's photos render a "perfect ruin" in the picturesque tradition, they also succeed in framing and revealing the representational agency of the High Line itself before the design was implemented: The ongoing processes of growth and decay, manifested through successional vegetation and emergent ecologies form the most transgressive elements, visualizing the threat to the systems of social and spatial order operating on and around the sites.

${ }^{28}$ It could of course be argued that the planting design itself provides experiences of non-human process, but these processes are so tightly controlled and reduced to a material means to provide an expected appearance that the human aspect is dominant to the point of being exclusive.

${ }^{29}$ Aesthetics are defined here as complex human-environment relationships (Berleant 1992), not just a normative visual practice, and proposed as everyday "aesthetic experience" - in particular as the ability to interact with urban nature, with nonhuman processes and their physical expressions. Not only is this experience considered enjoyable and contributes to the overall quality of life, it is also a critical precondition to imagine and articulate alternative relationships between the individual and collective self and urban nature and nature in general (e.g. Tuan 1974, Louv 2005, Hester 2006).

${ }^{30}$ Michel DeCerteau, "Walking in the City," in The Practice of Everyday Life, ed. Michel DeCerteau (Berkeley: University of California, 1984), 91-110. 
${ }^{31}$ Cronon (1992) provides an account of the problems inherent in environmental narratives. By extension, narratives that are "environmentalized" are equally or even more problematic.

${ }^{32}$ Yi Fu Tuan, Escapism (Baltimore: Johns Hopkins University Press, 1998.

${ }^{33}$ Jürgen Habermas, The Structural Transformation of the Public Sphere: An Inquiry into a Category of Bourgeois Society (Cambridge: The MIT Press 1989).

${ }^{34}$ Nancy Fraser, "Rethinking the Public Sphere: A Contribution to the Critique of Actually Existing Democracy," in Habermas and the Public Sphere, ed. Craig Calhoun (Cambridge: MIT Press, 1992), 109-142.

${ }^{35}$ This benevolent appearance is the "pastoral" within picturesque traditions, as opposed to the awe-inducing experience of the "sublime." See also Haraway 1991 on the notion of "domestication."

${ }^{36}$ Frederic Turner, "The Invented Landscape," in Beyond Preservation: Restoring and Inventing Landscapes, ed. Dwight Baldwin et al. (Minneapolis: University of Minnesota Press, 1994), 39-42.

${ }^{37}$ David Harvey, Justice, Nature, and the Geography of Difference (London: Blackwell, 1996) and David Harvey, Rebel Cities: from the Right to the City to the Urban Revolution (London: Verso, 2012).

${ }^{38}$ Aesthetics of (ecological) performance vs. (ecological) performance of aesthetics is a key dialectic in the analysis of the relationship between environmental aesthetics and environmental justice as it is played out on post-industrial sites and attempts to construe and instrumentalize versions and visions of 'urban nature' in the context of urban transformation. "Aesthetics of (ecological) performance" foreground the processes that occur on a site as they produce somewhat open-ended aesthetic experiences, whilst the (ecological) performance of aesthetics aim at creating and controlling a particular aesthetic experience and constructs or manipulates ecological processes and the resultant conditions to that end. These frameworks allow exploration of the constitutive function of the picturesque tradition and its aesthetic and ideological aspects in the construction of "urban nature," in particular as it addresses the appearance, performance and agency of emergent successional and transgressive ecologies.

${ }^{39}$ Guy Debord, La Societe' du Spectacle (Paris: Editions Buchet-Chastel, 1967).

${ }^{40}$ Jean Baudrillard, Simulacres et Simulation (Paris: Éditions Galilée, 1981).

41 See Joern Langhorst, "Re-Presenting Transgressive Ecologies: Post-Industrial Sites as Contested Terrains," Local Environment: The International Journal of Justice and Sustainability, Special Issue on "Post-industrial urban ecologies (2014), DOI: 10.1080/13549839.2014.928813; Susan Herrington, "Framed Again: the Picturesque Aesthetics of Contemporary Landscapes," Landscape Journal 25, no. 1 (2006): 22-37 and Elizabeth Meyer, "Seized by Sublime Sentiments: Between Terra Firma and Terra Incognita," in Richard Haag: Bloedel Reserve and Gas Works Park, ed. William Saunders (New York: Princeton Architectural Press, 1998), 5-28.

${ }^{42}$ Denis Cosgrove, Social Formation and Symbolic Landscape (Madison: University of Wisconsin Press, 1998), XVIII.

${ }^{43}$ Denis Cosgrove, Social Formation and Symbolic Landscape (Madison: University of Wisconsin Press, 1998); James Corner, "Representation and Landscape: Drawing and Making in the Landscape Medium," Word and Image 8, no. 3 (1992): 243-275 and Joern Langhorst, "Re-Presenting Transgressive Ecologies: Post-Industrial Sites as Contested Terrains, " Local Environment: The International Journal of Justice and Sustainability, Special Issue on Post-industrial urban ecologies (2014), DOI: 10.1080/13549839.2014.928813.

${ }^{44}$ Urban renewal and gentrification processes were already well on their way and displaced large numbers of the poorer residents before the High Line, but it will without doubt be instrumental in accelerating these processes (Cataldi et al. 2011:377). For possible relationships between emergent and transgressive ecologies and the "socially transgressive," see also Hard 1995 and Edensor 2005.

${ }^{45}$ This phenomenon is attributed to Frank Gehry's Guggenheim Museum in Bilbao, Spain (1997) and the transformation of a mostly industrial, neglected and abandoned neighborhood in its wake.

46 "The Resilience of Neoliberal Urbanism," Tom Slater, accessed 3 February 2014, http://www.opendemocracy.net/opensecurity/tom-slater/resilience-of-neoliberal-urbanism.

${ }^{47}$ The concept of aesthetic justice has been argued extensively by Beardsley (1982). For a critique in the context of spatial design and urban planning, see Mattila (2002).

48 Tilley 1994, Ingold 2000, Huyssen 2003, Creswell 2004 provide critical frameworks to interrogate this participatory formation of space and place. 


\section{Bibliography:}

Baudrillard, Jean. Simulacres et Simulation. Paris: Éditions Galilée, 1981.

Beardsley, Monroe C. "Aesthetic Welfare, Aesthetic Justice and Educational Policy." In The Aesthetic Point of View: Selected Essays: Monroe C. Beardsley, edited by M.J.Wreen and D.M. Callen, 111-124. London: Cornell University Press, 1982.

Berleant, Arnold. The Aesthetics of Environment. Philadelphia: Temple University Press, 1992.

Casey, Edward. "Going Wild in the Land." In Getting Back into Place: Toward a New Understanding of the Place-World, Edward Casey, 222-268. Bloomington: Indiana University Press, 2009.

Cataldi, Michael et al. "Residues of a Dream World: The High Line, 2011." Theory, Culture, Society 28, no. 7-8 (2011): 358-389.

Corner, James. "A Discourse on Theory II: Three Tyrannies of Contemporary Theory and the Alternative of Hermeneutics." Landscape Journal 10, no. 2 (1991): 115-133.

Corner, James. "Representation and Landscape: Drawing and Making in the Landscape Medium." Word and Image 8, no. 3 (1992): 243-275.

Corner, James. "Ecology and Landscape as Agents of Creativity." In Ecological Design and Planning, edited by G. Thompson and Frederic Steiner, 81-108. New York: John Wiley and Sons, 1997.

Corner, James. "Recovering Landscape as Cultural Practice." In Recovering Landscape: Essays in Contemporary Landscape Architecture, edited by James Corner, 2-26. New York: Princeton Architectural Press, 1999.

Cosgrove, Denis. Social Formation and Symbolic Landscape. Madison: University of Wisconsin Press, 1998.

Creswell, Timothy. Place. A Short Introduction. Oxford: Blackwell, 2004.

Cronon, William. "A Place for Stories: Nature, History and Narrative." The Journal of American History 78, no. 4 (1992): 1347-1376.

Cronon, William. "The Trouble with Wilderness; or, Getting Back to the Wrong Nature." In Uncommon Ground: Rethinking the Human Place in Nature, edited by William Cronon, 6990. New York: W. Norton, 1996.

DeCerteau, Michel. "Walking in the City." In The Practice of Everyday Life, edited by Michel DeCerteau, 91-110. Berkeley: University of California, 1984.

Debord, Guy. La Societe’ du Spectacle. Paris: editions Buchet-Chastel, 1967.

Edensor, Tim. Industrial Ruins: Spaces, Aesthetics and Materiality. London: Berg, 2005.

Evernden, Neil. The Social Creation of Nature. Baltimore: Johns Hopkins University Press, 1992.

Foster, Jennifer. "Off Track, in Nature: Constructing Ecology on Old Rail Lines in Paris and New York." Nature and Culture 5, no. 3 (2010): 316-337.

Fraser, Nancy. "Rethinking the Public Sphere: a Contribution to the Critique of Actually Existing Democracy." In Habermas and the Public Sphere, edited by Craig Calhoun, 109-142. Cambridge: MIT Press,

Haraway, Donna. Simians, Cyborgs and Women: The Reinvention of Nature. New York: Routledge, 1991.

Hard, Gerhart. Spuren und Spurenleser: Zur Theorie und Aesthetik des Spurenlesens in der Vegetation und anderswo. Osnabrueck: Universitaetsverlag Rasch, 1995.

Harvey, David. Social Justice and the City. London: Edward Arnold, 1973.

Harvey, David. Justice, Nature, and the Geography of Difference. London: Blackwell, 1996.

Harvey, David. Rebel Cities: from the Right to the City to the Urban Revolution. London: Verso, 2012. 
Herrington, Susan. "Framed Again: the Picturesque Aesthetics of Contemporary Landscapes." Landscape Journal 25, no. 1 (2006): 22-37.

Hubacek, Klaus and Kronenberg, Jakub. "Synthesizing Different Perspectives on the Value of Urban Ecosystem Services." Landscape and Urban Planning 109, Special issue on "Ecosystem Services" (2013): 1-6.

Ingold, Tim. "The Temporality of Landscape." In The Perception of the Environment: Essays on Livelihood, Dwelling and Skill, edited by Tim Ingold, 189-208. London: Routledge, 2000.

Iovine, Julie. "All Aboard the High Line.” The Wall Street Journal, 23 June 2009.

Habermas, Jürgen. The Structural Transformation of the Public Sphere: An Inquiry into a Category of Bourgeois Society. Cambridge: The MIT Press, 1989.

Herrington, Susan. "Framed Again: the Picturesque Aesthetics of Contemporary Landscapes." Landscape Journal 25, no. 1 (2006): 22-37.

Hester, Randolph. Design for Ecological Democracy. Boston: MIT Press, 2006.

Langhorst, Joern. "Re-Covering Landscapes: Derelict and Abandoned Sites as Contested Terrains." ICON: The Journal of the International Committee for the History of Technology 10 (2004): 65-80.

Langhorst, Joern. "Re-Presenting Transgressive Ecologies: Post-Industrial Sites as Contested Terrains." Local Environment: The International Journal of Justice and Sustainability Special Issue on "Post-industrial urban ecologies" (2014): 1110-1133. DOI: 10.1080/13549839.2014.928813.

Lefebvre, Henri. "Right to the City." In Lefebvre, Writings on Cities, edited by E. Kofman and E. Lebas, 63-177. Oxford: Basil Blackwell, 1996.

Lefebvre, Henri. The Production of Space. Oxford: Basil Blackwell, 1991.

Lynch, Kevin. Image of the City. Cambridge: The M.I.T. Press, 1960.

Mattila, Hanna. Aesthetic justice and urban planning: who ought to have the right to design cities? GeoJournal 58, no. 2-3 (2002): 131-138.

Meyer, Elizabeth. "Seized by Sublime Sentiments: Between Terra Firma and Terra Incognita." In Richard Haag: Bloedel Reserve and Gas Works Park, edited by William Saunders, 5-28. New York: Princeton Architectural Press, 1998.

Mitchell, Don. Right To The City: Social Justice and the Fight for Public Space. New York: Guilford, 2003.

Mitchell, WJT. Landscape and Power. Chicago: University of Chicago Press, 1994.

Mostafavi, Moshen. "Why Ecological Urbanism? Why Now?" In Ecological Urbanism, edited by Moshen Mostafavi, and Gary Doherty, 12-53. Cambridge: Lars Müller, 2010.

Oelschlager, Max. The Idea of Wilderness: From Prehistory to the Age of Ecology. New Haven: Yale University Press, 1991 .

Poole, Kathy. "Potentials of Landscape as Infrastructure Part 1: Six and a Half Degrees of Infrastructure." In The MESH book: infrastructure/landscape, edited by Julian Raxworthy and Jessica Blood, 18-49. Melbourne: RMIT Press, 2005.

Poole, Kathy. "Potentials of Landscape as Infrastructure Part 2: Creative Infrastructures - Dynamic Convergences of Ecology, Infrastructure and Civic Life." In The MESH book: infrastructure/landscape, edited by Julian Raxworthy and Jessica Blood, 180-199. Melbourne: RMIT Press, 2005.

Purcell, Mark. The Down-Deep Delight of Democracy. Malden: Wiley-Blackwell, 2013.

Raxworthy, Julian and Blood, Jessica. Editors. The MESH book: infrastructure/landscape. Melbourne: RMIT Press, 2005. 
Slater, Tom. "The Resilience of Neoliberal Urbanism." Accessed 3 February 2014. http://www.opendemocracy.net/opensecurity/tom-slater/resilience-of-neoliberal-urbanism.

Smith, Neil. Uneven Development: Nature, Capital and the Production of Space. Oxford: Blackwell, 1984.

Soja, Edward. Thirdspace. Malden: Blackwell, 1996.

Swyngedouw, Erik. "Trouble with Nature: Ecology as the New Opium for the People." In Conceptual Challenges for Planning Theory, edited by Jean Hillier and Patsy Healey, 299-320. Farnham: Ashgate, 2010.

Swyngedouw, Erik. "Insurgent Urbanity and the Political City." In Ethics of the Urban: The City and the Spaces of the Political, edited by Moshsen Mostafavi. Zurich: Lars Müller Publishers, forthcoming.

Talen, Emily. "A Tire in the Park." Accessed 14 January 2012. http://bettercities.net/newsopinion/blogs/emily-talen/13579/tire-park.

Tilley, Christopher. A Phenomenology of Landscape. Places, Paths and Monuments. Oxford: Berg, 1994.

Tuan, Yi Fu. Topophilia: A Study of Environmental Perception, Attitudes, and Values. Englewood Cliffs: Prentice-Hall, 1974.

Tuan, Yi Fu. Escapism. Baltimore: Johns Hopkins University Press, 1998.

Turner, Frederic. "The Invented Landscape." In Beyond Preservation: Restoring and Inventing Landscapes, edited by Dwight Baldwin et al, 35-66. Minneapolis: University of Minnesota Press, 1994.

Wilson, Japhy and Swyngedouw, Erik, editors. The Post-Political and Its Discontents. Spaces of Depoliticisation, Spectres of Radical Politics. Edinburgh: Edinburgh University Press, 2014. 